\title{
The Effect Of Corporate Ethical Values On Accountants' Perceptions Of Social Responsibility
}

\author{
Rafik Z. Elias, (E-mail: rafike@zlatech.com), California State University, Los Angeles
}

\begin{abstract}
Significant research has concluded that corporations have a social responsibility to stakeholders beyond maximizing shareholders' wealth. The current study examines the relationship between corporate ethical values and the perception of the importance of corporate social responsibility. A total of 583 CPAs in public accounting, industry and academia completed a survey designed to measure the importance of corporate social responsibility on profitability, long-term success and short-term success before Enron and Worldcom declared bankruptcy. The results indicated that CPAs employed in organizations with high (low) ethical values perceived corporate social responsibility to be more (less) important in profitability and long-term success and less (more) important in short-term success of the firm.
\end{abstract}

\section{INTRODUCTION}

ignificant research in the last half a century indicated that corporations have a responsibility to society that goes beyond maximizing shareholders' value (Orlitzky and Benjamin, 2001). Recent high-profile corporate bankruptcies such as Enron and WorldCom and the SEC's investigation of many others have reinvigorated the debate over corporate responsibility to various stakeholders. Some authors have suggested that responsibility to external constituents has to originate from within the company, more specifically from its corporate culture (Millman, 2002).

The purpose of this study is to investigate the relationship between corporate ethical values and the perception of the importance of ethics and social responsibility in organizational effectiveness. The study investigates whether accountants employed in more ethical organizations, according to their own perception, are more likely to value social responsibility. Recent high-profile corporate scandals such as Enron and Worldcom have focused the public's attention on accountants in public accounting and industry. This study uses a sample of accounting practitioners in public and private accounting and accounting faculty to determine if perceived ethical values in their work environment has an effect on their perception of social responsibility. The results will shed light on whether there were warning signals in the accounting profession before the major recent bankruptcies. The findings will also shed light on the importance of integrating ethics into the corporate culture of accounting organizations and academic institutions.

The paper is organized as follows: The following section presents a background on the importance of social responsibility to organizational effectiveness and corporate ethical values, especially in light of recent corporate scandals. The purpose of the study and its hypotheses are presented next, followed by a discussion of sampling and measurement. The results are then presented, followed by a discussion of the findings and their implications for the accounting profession. 


\section{LITERATURE REVIEW}

\section{Corporate Social Responsibility And Effectiveness}

Bowen (1953) was a pioneer in advocating that business has an obligation to society. He noted that managers have to "make those decisions and pursue those policies that are desirable in terms of the objectives of our society" (Bowen, 1953, 6).

Over the following decades, this point of view has been extensively debated and mostly supported. On one hand, Friedman and Friedman (1981) noted that the only objective of managers should be to maximize shareholders' wealth, and that spending corporate resources to satisfy social concerns represents an agency problem. Carson (1993) supported this viewpoint and argued that managers play the role of unelected public officials when they use the company's resources for the social good instead of maximizing stockholders' value. On the other hand, another viewpoint argues that public visibility of corporations requires them to be socially responsible (Davis, 1974) and that business has a responsibility toward solving problems of social concern (Monsen, 1974). The latter viewpoint has received considerable support in the literature.

Davis (1974) referred to corporate social responsibility as "The Iron Law of Responsibility" in the sense that businesses that do not use their power for the social good will tend to lose it. Significant research has been conducted to investigate the consequences of corporate social responsibility. Zahra and LaTour (1987) examined the relationship between corporate social responsibility and effectiveness. They concluded that social responsibility and effectiveness are two related multidimensional constructs. They defined corporate effectiveness as entrepreneurial viability, satisfaction of the public needs as well as profit and growth. Lachman and Wolfe (1997) linked the concepts of social responsibility and effectiveness indicating that they are interfaced, and quite often intersect in the corporate mission. Singhapakdi et al. (1995) investigated whether marketers believed that social responsibility and corporate effectiveness were related concepts. The results indicated that marketers supported this link and viewed social responsibility as an important determinant of corporate effectiveness. The authors argued that social responsibility neither defines nor causes effectiveness, but rather is one of its determinants (Singhapakdi et al., 1995).

In a further investigation of effectiveness, Singhapakdi et al. (1996) defined it as profitability, long-term success of the firm and short-term success. Extensive research points to the importance of social responsibility in all three factors. Waddock and Graves (1997) developed "The Theory of Good Management". They showed that good social responsibility performance will be rewarded with stronger financial performance. Orlitzky et al. (2003) conducted a meta-analysis of studies investigating the relationship between social responsibility and profitability and found a significant correlation between social responsibility and accounting as well as marketing-based measures of performance. Research also pointed to the importance of social responsibility in the long-term success of the firm, rather than the short-term. Miller (1998) criticized corporations for their preoccupation with short-term shareholders' profits and advocated the use of long-term measures of performance. Porter and Kramer (2002) also noted that many corporations institute short-term philanthropy programs as an indication of social responsibility, without an increase in long-term strategies to benefit the communities they serve. The current study uses the definition of effectiveness presented by Singhapakdi et al. (1996).

\section{Corporate Fraud And Failures}

Defending the viewpoint that corporations have a social responsibility, Freeman (1984) advocated The Stakeholder Theory, which became the dominant paradigm in corporate social responsibility (McWilliams and Siegel, 2001). The theory holds that corporations are responsible to many different stakeholders such as consumers, investors, employees and the general public (Freeman, 1984).

The public's confidence in corporate behavior has been shaken repeatedly in the last decades and the stakeholder theory has received increased attention. For example, recently, major corporations such as Enron and WorldCom have declared bankruptcies. Many other well-known corporations such as Xerox were the subjects of SEC investigation. In fact, as of July 2001, the SEC reported 260 fraud investigations, a significant increase over previous 
years (Martin et al., 2002). The majority of these investigations involved accounting practices known as "earnings management" committed by the most senior financial executives. These practices paint a financial picture of the company that does not match reality and the SEC has taken an increasing interest in these accounting maneuvers in recent years (Levitt, 1998). These accounting activities also resulted in the bankruptcies of Enron and WorldCom. Clearly, these bankruptcies were detrimental to all stakeholders.

The latest bankruptcies and investigations refocused the attention on corporate ethics and social responsibility. Different viewpoints have been advocated as causes of these failures. Millman (2002) questioned whether the notion of managers thinking like shareholders could be the cause of the scandals. Under these conditions, managers as well as legal and financial advisors had interests tied heavily to those of investors. Under these conditions, it is difficult for someone to step in and argue that ethics should be considered (Millman, 2002). Madison (2002) argued that accounting education programs have become very technical in nature. He noted that educational institutions must intensify their efforts in teaching ethics in the classroom.

Even though some authors argued for more ethics education, most analysts of business failures in general concluded that the culprit is the corporate culture. Priest (2002) noted that bankrupt firms had corporate cultures that valued innovation, aggressiveness and risk-taking. They valued not only going close to the edge but pushing the edge. In an analysis of fraudulent reporting firms, Robinson-Backmon and Finney (1999) investigated the common characteristics of such firms. Research has shown that the perpetrators of accounting fraud were typically at the top of the organization (Loebbecke et al., 1989). Robinson-Backmon and Finney (1999) found that fraudulent corporations were typically small- to mid-size, employ large accounting firms as auditors, and misstate earnings using accounting maneuvers. Further investigation of these companies' ethics programs revealed that the tone-setters were top managers such as CEOs and CFOs. In addition, in fraudulent companies, top managers were held responsible for compliance with the ethics code, which was not used as a measure of management performance (Robinson-Backmon and Finney, 1999).

Even before the recent bankruptcies, the public had a negative view of corporate social responsibility. A Harris poll conducted in 2000 found consumers believing that having large profits was more important to corporations than developing safe, reliable, quality products for the consumer (Business Week, 2000). Only a quarter of those polled agreed that corporations were behaving in an ethical manner.

Many authors argued that several warning signals existed before the scandals were revealed. Kaufman (2002) was alarmed by the fact that portfolios were measured over short-term horizons, at most yearly. He noted that underperformance was penalized very quickly. Higson (2001) posited that Enron's involvement with special purpose entities was a well-known fact on Wall Street for years. The investment professionals were busy admiring Enron's creativity and aggressiveness in market expansion without taking a harder look at how it will make money in those new markets (Higson, 2001).

\section{Corporate Ethical Values}

In the aftermath of corporate bankruptcies, there is increasing public interest in a corporation's ethical environment. Clark and Leonard (1998) attributed this interest to the fact that unethical decisions frequently undermine the performance of many organizations. Baumhart (1961) provided early evidence of the importance of the ethical environment. He surveyed managers and found that the top factors influencing unethical behavior included behavior of superiors, behavior of peers, and formal organizational codes of ethics. In order to study the organizational ethical environment, studies have distinguished between ethical culture and ethical values. Hunt et al. (1989) conducted a pioneering study to distinguish between the two concepts and concluded that corporate ethical values are the central dimension of corporate culture (Hunt et al., 1989, 79). They defined corporate ethical values as a composite of the individual ethical values of managers and both the formal and informal policies on ethics of the organization (Hunt et al., 1989, 79).

Significant research has been conducted to investigate the consequences of positive corporate ethical values. Deal and Kennedy (1982) noted that values convey a sense of identity to the organization's members, enhance the 
stability of its social system and direct and guide managers' decisions. Peters and Waterman (1982) pointed out that virtually all superior performance firms have at the core a well-defined set of shared values, particularly ethical values. A number of studies also found that there is a significant positive relationship between corporate ethical values and organizational commitment (Hunt et al., 1989), organizational dissent (Valentine et al., 2001), external whistleblowing (Sims and Keenan, 1998) and ethical behavioral intentions (Vitell et al., 2003).

Based on research on the beneficial influences of corporate ethical values, many companies have ascertained the best method of incorporating ethical values in their culture. This is especially important since Fogarty (1992) concluded that once employees enter an accounting firm, for example, a variety of socialization methods can more fully integrate them in the company's environment. The debate on the integration of values into culture has centered on whether people or environments are the primary determinants of organizational behavior. Schneider $(1987,440)$ advocated the concept that people are not randomly assigned to organizations, rather they are attracted to, are selected by, and remain in a particular setting. He also argued that people who remain with an organization share many common homogenous personal attributes compared to those who were initially attracted to the firm (Schneider, 1987, 444). According to Schneider, the people make the difference in setting the ethical environment. Weaver et al. (1999) conducted a study to investigate the source of an organization's ethical environment. They concluded that environmental factors lead organizations to implement ethics programs, codes and telephone lines. However, much of the guidance in implementing these programs comes from top managers and their commitment to ethics. Therefore, management's moral outlook is an important influence on a company's ethical structures and practices (Etzioni, 1988).

\section{STUDY OBJECTIVES AND HYPOTHESES}

The purpose of the study is to investigate the relationship between corporate ethical values, as perceived by accountants in their own organizations, and the importance of social responsibility. The study is motivated by the increased scrutiny of accountants after the corporate scandals. Since accountants are primary corporate stakeholders, as employees, managers and auditors, it is important to determine if there were signals in the profession before Enron and Worldcom. Accountants are also employed in a variety of occupations. Therefore, the study evaluates whether their perception of corporate ethical values is a function of their occupation. Based on executives' wrongdoing uncovered in recent investigations, the first hypothesis of the study assumes that accountants in industry were working in organizations with lower ethical values compared to those in public accounting and academia. $\mathrm{H} 1$ is therefore stated as follows:

H1: Accountants in industry would have a lower perception of their organizations' ethical values compared to accountants in public accounting and academia.

The study investigates accountants' perception of the importance of corporate ethical values on social responsibility and effectiveness. Effectiveness is defined similar to Singhapakdi et al. (1996) as: Profitability, longterm success and short-term success of the firm. Based on previous research findings (see Orliztky et al. (2003) for a meta-analysis), the study hypothesizes that perception of corporate ethical values will play an important positive role in the perception of the importance of social responsibility in profitability. Therefore $\mathrm{H} 2$ is stated as:

H2: There is a positive relationship between corporate ethical values and accountants' perception of the importance of social responsibility in profitability.

The study also assumes that accountants will view a positive link between corporate ethical values and longterm success of the firm and a negative link between ethical values and short-term success. That means that high ethical values will tend to focus accountants' attention on long-term goals and success, instead of short-term success and survival. $\mathrm{H} 3$ and $\mathrm{H} 4$ are presented as follows:

H3: There is a positive relationship between accountants' perceptions of corporate ethical values and their perception of the importance of social responsibility in long-term success. 
H4: There is a negative relationship between accountants' perceptions of corporate ethical values and their perception of the importance of social responsibility in short-term success.

\section{RESEARCH METHOD}

\section{Sample Selection}

The sample for this study consisted of CPAs employed in public accounting, industry and academia. A database of 4,200 names and addresses of CPAs was obtained from the American Institute of Certified Public Accountants (AICPA). The database consisted of 1,600 CPAs in public accounting, 1,600 CPAs in industry and 1,000 CPAs who are accounting faculty. The selection of CPAs in all occupations was random and national. CPAs in public accounting and industry held different titles in different industries and CPAs in academia were employed in all size and type institutions.

The selected CPAs were contacted by mail. The survey was conducted a few months before the news of Enron's accounting trouble became public information. Each CPA was sent a cover letter explaining that the purpose of the study is to examine perception of the importance of social responsibility.

A postage-paid return envelope was enclosed and respondents were assured of confidentiality. Each CPA also received instruments measuring social responsibility and corporate ethical values. Many demographic questions were also included. The results of demographic analyses are the subject of an on-going study and are beyond the scope of the current study.

\section{Measures}

In order to measure the perceived role of ethics and social responsibility in organizational effectiveness (PRESOR), an instrument developed by Singhapakdi et al. (1996) was used. The instrument consists of 13 statements and yields three factors: Profitability, long-term success and short-term success. Every respondent records his/her agreement with each statement on a nine-point scale ranging from strongly disagree to strongly agree. A respondent who scores high on the profitability factor believes that social responsibility is important in profitability and organizational competitiveness.

A respondent who scores high in the long-term success factor believes that social responsibility plays a major role in determining long-term success of the firm including overall effectiveness and employee morale. A respondent who scores high on the short-term success factor believes that social responsibility is important in the short-term such as stockholders' happiness and making profits by any means (Singhapakdi et al., 1996).

The instrument has been extensively tested and validated. Original reliabilities ranged from .71 to .57 (Singhapakdi et al. 1996). In this study, coefficient alphas ranged from .75 to .62 for the full sample. Several studies have been conducted with PRESOR. An earlier version of PRESOR containing three factors: Good ethics is good business, profits are not paramount, and quality and communication was used by Singhapakdi et al. (1995) in a survey of marketers. The results indicated that marketers viewed corporate ethical values as an important determinant of the importance of social responsibility in effectiveness. The authors concluded that marketing managers do not need to fear that they are sacrificing ethics when they stress socially responsible behavior. Marta et al. (2000) compared the perception of the importance of social responsibility in effectiveness across cultures. Students from the U.S. and New Zealand viewed social responsibility to be more important in business compared to students from India. In a study involving accountants, Elias (2002) found a significant relationship between perception of social responsibility, using PRESOR, and ethical perception of selected earnings management actions. Accountants who perceived social responsibility to be more important to effectiveness were more likely to view earnings management actions as more unethical.

In order to measure the perception of corporate ethical values, an instrument developed by Hunt et al. (1989) was used. The instrument consisted of five statements resulting in an overall score for corporate ethical values. Each 
respondent records his/her agreement with the statement on a seven-point scale ranging from strongly disagree to strongly agree. Hunt et al. $(1989,84)$ indicated that the instrument is designed to capture three broad-based perceptions: (1) the degree to which employees perceive managers are acting ethically in their organization, (2) the degree to which employees perceive managers are concerned about the ethical issues and (3) the extent to which employees perceive that ethical (unethical) behavior is rewarded (punished) in their organization. This instrument has also been extensively tested and validated with original reliability of .78 (Hunt et al., 1989). In this study coefficient alpha was .76 using the full sample. A respondent who scores high on the instrument (after considering reverse-scored items) believes that his/her organization has high ethical values.

This scale has also been used extensively in ethics and organizational behavior research. Hunt et al. (1989) found that corporate ethical values were positively related to organizational commitment. Other studies also concluded that corporate ethical values were related to person-organization fit (Valentine et al., 2002), organizational dissent (Valentine et al., 2001) and ethical behavioral intention (Vitell et al., 2003).

\section{STUDY RESULTS}

An analysis of postmarks on the return envelopes indicated that a national sample has been achieved. Overall, there were 604 responses. After disregarding responses with missing information, the useable sample was 583 CPAs, representing a useable response rate of $13.8 \%$. They consisted of 175 CPAs in public accounting (10.9\%), 163 CPAs in industry (10.1\%), and 245 CPAs employed in academia (24.5\%).

A common concern in survey-based studies is the potential for nonresponse bias. In order to address this issue, the respondents were divided into two groups based on the mean response time. A comparison of early and late respondents on the corporate ethical values and social responsibility perception scales produced no significant differences. However, due to the low response rate in this study, nonresponse bias remains a concern and the results of this study may not be generalizable to the CPA population at large. This represents a limitation of the current study.

The first hypothesis investigated whether CPAs in different occupations would have different perceptions of corporate ethical values in their organization. The mean responses on the corporate ethical values scale are presented in Table 1.

Table 1: Perceptions of Corporate Ethical Values $(\mathrm{N}=583)$

\begin{tabular}{|c|c|c|}
\hline Occupation & Number of Respondents & $\begin{array}{c}\text { Mean Perception } \\
\text { of Corporate Ethical Values (SD) }\end{array}$ \\
\hline Public accounting & 173 & $5.38(.73)^{* * *} \quad \# \#$ \\
\hline Industry accounting & 165 & $4.62(.79) * * *+++$ \\
\hline Accounting faculty & 245 & $5.51(.92) \quad+++\# \#$ \\
\hline $\begin{array}{l}\text { Corporate ethical values: } \\
1=\text { strongly disagree } \\
7=\text { strongly agree } \\
* * * \text { Significant at the } .01 \text { level } \\
+++ \text { Significant at the } .01 \text { level } \\
\# \# \text { Significant at the } .05 \text { level }\end{array}$ & & \\
\hline
\end{tabular}

A comparison of the means was performed among CPAs in different occupations. The results indicated that CPAs' perception of their corporate ethical values is a function of their occupation. CPAs employed in academic institutions had the highest agreement that their institution had high ethical values (Mean $=5.51$ ), followed by CPAs in public accounting (Mean = 5.38) and CPAs in industry (Mean = 4.62). The latter group's perception of corporate ethical values was near the mid-point of the scale (i.e. neutral). CPAs in industry viewed the ethical climate in their organization to be significantly lower compared to CPAs in public accounting and academia. 
The next series of tests concerned the relationship between corporate ethical values and the perception of social responsibility. The mean score of corporate ethical values was the independent variable and the mean scores of profitability, long-term success and short-term success were the dependent variables in separate regression analyses. Since the three groups of respondents were employed in different occupations, with different corporate ethical values' perception, they were treated separately in the following analyses. The results are presented in Table 2.

Table 2: Impact of Corporate Ethical Values on Social Responsibility

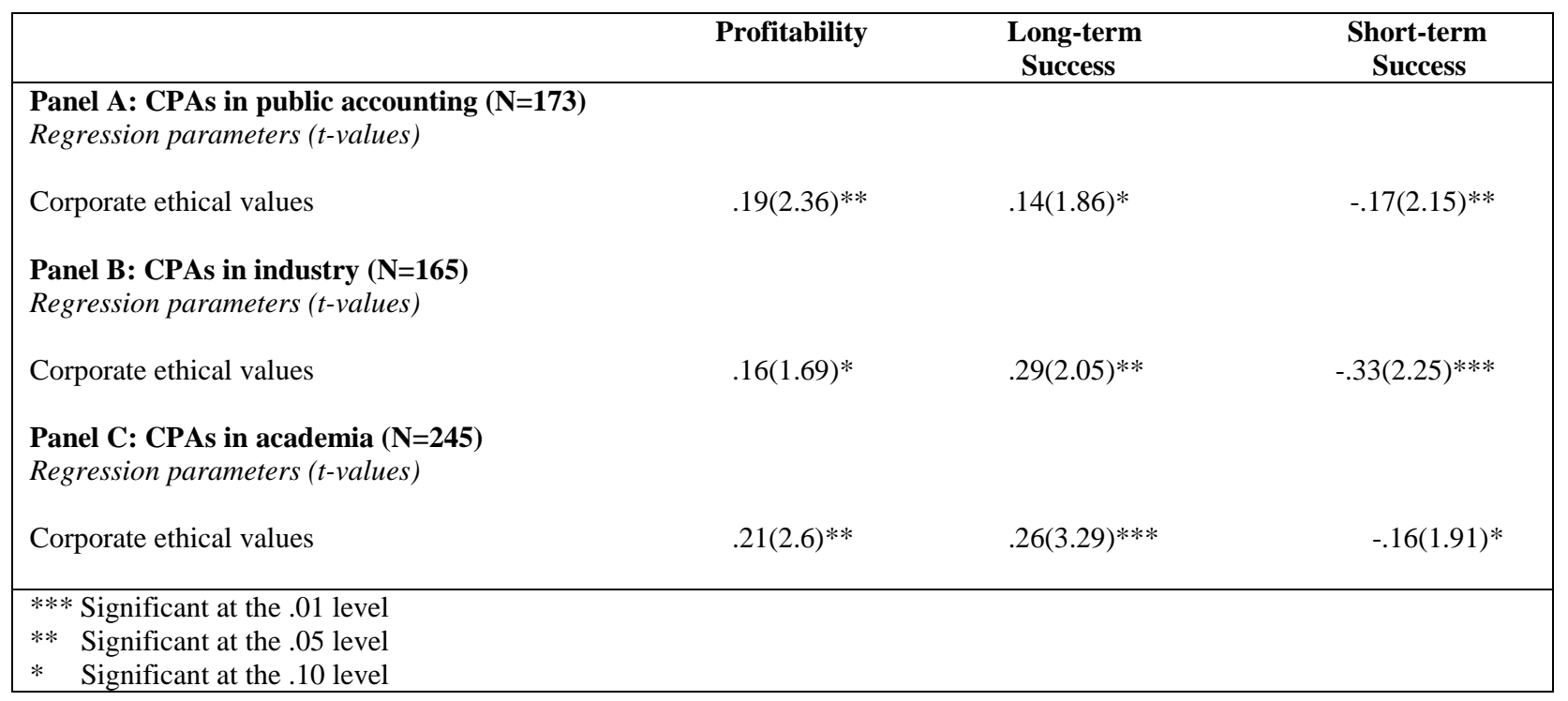

The results indicated that perception of corporate ethical values was significantly related to the perception of the importance of social responsibility in effectiveness. These results were consistent among CPAs in different occupations.

CPAs employed in organizations with high ethical values had a more positive perception of the importance of social responsibility in profitability and long-term success of the firm and a more negative perception of the importance in short-term success. These results provide support for $\mathrm{H} 2, \mathrm{H} 3$ and $\mathrm{H} 4$.

\section{DISCUSSION AND IMPLICATIONS IN THE AFTERMATH OF ENRON}

This study investigated the relationship between corporate ethical values and the perception of the importance of social responsibility in organizational effectiveness. Several findings emerged with implications for the accounting profession after Enron and Worldcom. Consistent with the position of Higson (2001), the results generally indicated that many warning signs existed in the accounting profession before the scandals were revealed.

CPAs in different occupations provided mixed perceptions of their organization's ethical values. CPAs in industry were neutral in their perception of their organization's ethical values. Since CPAs in industry are typically in charge of preparing the financial statements, these results are troubling and should be investigated further. Later investigation of Enron's organizational culture revealed that the company prominently displayed its ethics values, such as integrity and respect, in the organization's buildings (Spector, 2003). However, performance evaluation rarely included such values. Verschoor (2002) noted that Enron's ethics code lacked any effective method of ensuring compliance. 
More comforting results were obtained from public accounting and academia, especially among the latter group. Subsequent events such as the dismemberment of Arthur Andersen, Enron's auditors, have shaken the public's trust in the accounting profession. CPAs in public accounting viewed the ethical climate in their organization to be generally positive. Since these CPAs are in charge of preparing tax returns and auditing, it is comforting that they perceived their organizations to be ethical. It appears that inappropriate behavior by Andersen's partners and employees such as shredding documents was an isolated incident. In addition, it appears that educational institutions also foster positive ethical values as perceived by accounting faculty. These results are also comforting since accounting instructors are called upon to increase students' ethical awareness (Madison, 2002). Such awareness needs to start by educational institutions fostering ethical environments themselves.

The results also indicated that those accountants employed in ethical organizations viewed social responsibility to be important in organizational effectiveness. Accountants typically focused on the long-term aspect of effectiveness by positively linking corporate ethical values with profitability and long-term success. There was less emphasis on short-term success.

Accountants perceived corporate ethical values to be positively related to profitability. This finding confirms Orlitzky et al. (2003) who found that most research supported this link. Significant findings emerged regarding longterm and short-term success of the firm. Accountants in all occupations viewed corporate ethical values to be positively related to the long-term success of the firm. In the aftermath of Enron and WorldCom, many authors have advocated the importance of addressing all stakeholders' needs rather than merely shareholders'. Carson (2003) noted that Enron and Worldcom's executives may have rationalized their actions by appeal to The Stakeholder Theory advocated by Freeman (1984). The executives believed that maximizing stock price provided benefits to shareholders (Carson, 2003). Deakin and Konzelmann (2003) agreed with this analysis and noted that to assure long-term success, corporate governance can no longer confine its analysis to the relationship between managers, boards and shareholders, as was the case in Enron. Rather, the board must advance the interests of all shareholders (Deakin and Konzelmann, 2003). Willmott (2003) also advocated this approach in the aftermath of Enron and argued that corporation should address the long-term needs of local and wider communities. Barratt and Korac-Kakabadse (2002) also advocated the egalitarian treatment of all stakeholders and urged corporations to be more pluralistic in their operations.

Accountants in all occupations also perceived corporate ethical values to be negatively related to the shortterm success of the firm. In the case of Enron, later investigation revealed that the company established a "win at all costs" strategy that focused only on today's bottom line. The company's leadership promoted and retained only those employees that produced consistently without regard to ethics (Sims and Brinkmann, 2003). Spector (2003) emphasized the short-term focus of Enron's executives and used their stock options as examples. In testimony before Congress, Jeff Skilling, an Enron top executive, explained that stock options were used to reduce compensation expenses and increase the appearance of profitability. The increasing reliance on stock options as compensation invited the short-term focus exhibited by Enron's executives of maximizing stock price long enough to cash out the options (Spector, 2003).

The current study lends itself to many future research opportunities. For example, further research can investigate the neutral perception of corporate ethical values exhibited by industry accountants compared to other accountants. Interesting questions are whether this perception is more prevalent in certain industries and if so, what are the reasons for it? Were there specific actions undertaken by managers that led to this perception or was there a lack of communication about the importance of ethics? In addition, since the current study was conducted before the corporate scandals, it is interesting to replicate it after these major corporate failures. Of particular interest is whether increased public scrutiny of corporate executives resulted in a change in the perception of ethical values. The answers to these questions can provide guidance in improving the organizational ethical climate in industry. 


\section{REFERENCES}

1. Baumhart, R. C., How Ethical are Businessmen, Harvard Business Review Vol. 39, pp. 156-157, 1961.

2. Barratt, R. and N. Korac-Kakabadse, Developing Reflexive Corporate Leadership: The Role of the Nonexecutive Director, Corporate Governance: The International Journal of Effective Board Performance Vol. 2, pp. 32-36, 2002.

3. Bowen, H. R., Social Responsibilities of the Businessman, Harper \& Row, New York: NY, 1953.

4. Business Week, September 11, 2000 http://www.businessweek.com/2000/00-37/b3698004.htm.

5. Carson, T. L., Self-interest and Business Ethics: Some Lessons of the Recent Corporate Scandals, Journal of Business Ethics Vol. 43, pp. 389-394, 2003.

6. Carson, T. L., Friedman's Theory of Corporate Social Responsibility, Business \& Professional Ethics Journal Vol. 12, pp. 3-32, 1993.

7. Clark, M. A. and S. Leonard, Can Corporate Codes of Ethics Influence Behavior? Journal of Business Ethics Vol. 17, pp. 619-630, 1998.

8. Davis, K., The meaning and scope of social responsibility in J. W. McGuire (ed.), Contemporary Management: Issues and Viewpoints, Prentice Hall, Englewood Cliffs, NJ, 1974.

9. $\quad$ Deakin, S. and S. J. Konzelmann, After Enron: An Age of Enlightenment? Organization Vol. 10, pp. 583587, 2003.

10. Deal, T. E. and A. A. Kennedy, Corporate Culture, Addison-Wesley Publishing Company, Reading: MA, 1982.

11. Elias, R., Determinants of Earnings Management Ethics among Accountants, Journal of Business Ethics Vol. 40, pp. 33-45, 2002.

12. Etzioni, A, The Moral Dimension, Free Press, New York: NY, 1988.

13. Fogarty, T. J., Organizational Socialization in Accounting Firms: A Theoretical Framework and Agenda for Future Research, Accounting, Organizations \& Society Vol. 17, pp. 129-149, 1992.

14. Freeman, R., Strategic Management: A Stakeholder Perspective, Prentice Hall, Englewood Cliffs: NJ, 1984.

15. Friedman, M. and R. Friedman, Free to Choose. Avon, New York: NY, 1981.

16. Higson, C., Did Enron's Investors Fool Themselves? Business Strategy Review Vol. 12, pp. 1-6, 2001.

17. Hunt, S. D., V. R. Wood, and L. B. Chonko, Corporate Ethical Values and Organizational Commitment in Marketing, Journal of Marketing Vol. 53, pp. 79-90, 1989.

18. Kaufman, H., The Fallout from Enron: Lessons and Consequences, Vital Speeches of the Day Vol. 68, pp. 461-465, 2002.

19. Lachman, R. and R. A. Wolfe, The Interface of Organizational Effectiveness and Corporate Social Performance, Business \& Society Vol. 36, pp. 194-214, 1997.

20. Levitt, A., The numbers game, The CPA Journal Vol. 68, pp. 14-19, 1998.

21. Loebbecke, J. K., M. M. Eining and J. J. Willingham, Auditor's Experience with Material Irregularities: Frequency, Nature, and Detectability, Auditing: A Journal of Practice \& Theory Fall, pp. 1-29, 1989.

22. Madison, R. L., Is Failure to Teach Ethics the Causal Factor? Strategic Finance December, pp. 24, 63-64, 2002.

23. Marta, J. K. M., A. Singhapakdi, K. C. Rallapalli, and M. Joseph, Moral Philosophies, Ethical Perceptions, and Marketing Education: A Multi-country Analysis, Marketing Education Review Vol. 10, pp. 37-47, 2000.

24. Martin, D. R., G. R. Aldhizer, III, J. L. Campbell, and T. A. Baker, When Earnings Management Becomes Fraud, Internal Auditing Vol. 17, pp. 14-21, 2002.

25. McWilliams, A., and D. Siegel, Corporate Social Responsibility: A Theory of the Firm Perspective. Academy of Management Review Vol. 26, pp. 117-127, 2001.

26. Miller, R. A., Lifesizing an Era of Downsizing: An Ethical Quandary, Journal of Business Ethics Vol. 17, pp. 1693-1701, 1998.

27. Millman, G. J., New Scandals, Old Lessons: Financial Ethics after Enron, Financial Executive Vol. 18, pp. 16-19, 2002.

28. Monsen, R. J., The Social Attitudes of Management in J. W. McGuire (ed.), Contemporary Management: Issues and Viewpoints, Prentice Hall, Englewood Cliffs: NJ, 1974.

29. Orlitzky, M., F. L. Scmidt, and A. L. Rynes, Corporate Social and Financial Performance: A Meta-Analysis, Organization Studies Vol. 24, pp. 403-425, 2003. 
30. Orlitzky, B. Z. and J. D. Benjamin, Corporate Social Performance and Firm Risk: A Meta-analytic Review, Business \& Society Vol. 40, pp. 369-396, 2001.

31. Peters, T. J., and R. H. Waterman, In Search of Excellence, Harper \& Row, New York: NY, 1982.

32. Porter, M. E. and M. R. Kramer, The Competitive Advantage of Corporate Philanthropy, Harvard Business Review Vol. 80, pp. 56-65, 2002.

33. Priest, S., The Disconnect in Ethics Training, Across the Board, Sept/Oct., pp. 51-52, 2002.

34. Robin, D. P. and R. E. Reidenbach, Social Responsibility, Ethics and Marketing Strategy: Closing the Gap between Concept and Application, Journal of Marketing Vol. 51, pp. 44-58, 1987.

35. Robinson-Backmon, I. and S. G. Finney, The Characteristics of Fraudulent Reporting Firms-A Profile of Ethics Programs, Research on Accounting Ethics Vol. 5, pp. 77-93, 1999.

36. Schneider, B., The People Make the Place, Personnel Psychology Vol. 40, pp. 437-453, 1987.

37. Sims, R. R. and J. Brinkmann, Enron Ethics (Or: Culture Matters More than Codes), Journal of Business Ethics Vol. 45, pp. 243-256, 2003.

38. Sims, R. L. and J. P. Keenan, Predictors of External Whistleblowing: Organizational and Intrapersonal Variables, Journal of Business Ethics Vol. 17, pp. 411-421, 1998.

39. Singhapakdi, A., S. J. Vitell, K. C. Rallapalli, and K. L. Kraft, The Perceived Role of Ethics and Social Responsibility: A Scale Development, Journal of Business Ethics Vol. 15, pp. 1131-1140, 1996.

40. Singhapakdi, A., K. L. Kraft, S. J. Vitell, and K. C. Rallapalli, The Perceived Importance of Ethics and Social Responsibility on Organizational Effectiveness: A Survey of Marketers, Journal of the Academy of Marketing Science Vol. 23, pp. 49-56, 1995.

41. Spector, B., The Unindicted Co-conspirator, Organizational Dynamics Vol. 32, pp. 207-220, 2003.

42. Valentine, S., L. Godkin, and M. Lucero, Ethical Context, Organizational Commitment, and Personorganization Fit, Journal of Business Ethics Vol. 41, pp. 349-360, 2002.

43. Valentine, S., K. Young, L. Bailey, N. Barhoum, S. LaBure, N. Glover, and P. Isaac, Expressing Organizational Dissent: The Role of Ethical Ideology and Corporate Ethical Values, Journal of Business Strategies Vol. 18, pp. 71-89, 2001.

44. Verschoor, C. C., It Isn't Enough to Just Have a Code of Ethics, Strategic Finance Vol. 84, pp. 22-24, 2002.

45. Vitell, S. J., A. Bakir, J. G. P. Paolillo, E. R. Hidalgo, J. Al-Khatib, and M. Y. A. Rawwas, Ethical Judgments and Intentions: A Multinational Study of Marketing Professionals, Business Ethics: A European Review Vol. 12, pp. 151-171, 2003.

46. Waddock, S. A. and S. B. Graves, Corporate Social Performance-Financial Performance Link, Strategic Management Journal Vol. 18, pp. 303-320, 1997.

47. Weaver, G. R., L. K. Trevino, and P. L. Cochran, Corporate Ethics Programs as Control Systems: Influences of Executive Commitment and Environmental Factors, Academy of Management Journal Vol. 42, pp. 41-57, 1999.

48. Willmott, M., Citizen Brands: Corporate Citizenship, Trust and Branding, Brand Management Vol. 10, pp. 362-369, 2003.

49. Zahra, S. A. and M. S. LaTour, Corporate Social Responsibility and Organizational Effectiveness: A Multivariate Approach, Journal of Business Ethics Vol. 6, pp. 459-467, 1987. 